\title{
PEMODELAN APLIKASI MOBILE PELAYANAN PUBLIK DESA (SMART VILLAGE) BERBASIS CLOUD COMPUTING
}

\author{
Rabby Nazli \\ Fakultas Teknik, Universitas Islam Kuantan Singingi \\ Jl. Gatot Subroto KM.7 Jake teluk Kuantan Riau \\ email: rabbynazli@gmail.com
}

\begin{abstract}
Public service is a necessity that can not be negotiated in improving the quality of service every time, every agency or organization that provides public services certainly wants to provide the best service to everyone it serves. At present public services in the village Beringin Taluk Kec. Kuantan Tengah District Kuantan Singingi has done very well but there are some obstacles in terms of public services such as the absence of a safe data storage place so that data is easily lost and damaged. There is no integration between BUMDes in the village so that information cannot be reviewed periodically. There is no integrated media of information or complaints, so people need to come directly to the village office to find information and provide complaints. Modeling an application for cloud computing-based public services has contributed to increasing the achievement of the goals of a village to get to a smart village with an integrated system and facilitate the community to access all needs in terms of information and services.
\end{abstract}

Keywords: Public Service, Cloud Computing, Modelling, Smart Village

\begin{abstract}
Pelayanan publik merupakan kebutuhan yang tidak bisa ditawar dalam peningkatan mutu pelayanan setiap saatnya, setiap instansi maupun organisasi yang memberikan pelayanan publik tentunya ingin memberikan pelayanan terbaik kepada setiap orang yang dilayaninya. Saat ini pelayanan publik yang ada di desa Beringin Taluk Kec. Kuantan Tengah Kab. Kuantan Singingi sudah dilakukan dengan sangat baik namun ada beberapa kendala didalam hal pelayanan publik tersebut seperti belum adanya tempat penyimpanan data yang aman sehingga data mudah hilang dan rusak. Belum adanya integrasi antara BUMDes yang ada didesa sehingga informasi-informasi tidak bisa ditinjau secara berkala. Belum adanya media informasi ataupun media aduan dan keluhan yang terintegrasi sehingga masyarakat perlu datang langsung kekantor desa untuk mencari informasi dan memberikan aduan. Memodelkan sebuah aplikasi untuk pelayanan publik yang berbasis cloud computing memiliki kontribusi untuk meningkatkan pencapaian tujuan dari sebuah desa untuk menuju desa pintar dengan sebuah sistem yang terintegrasi dan memudahkan masyarakat dalam mengakses segala kebutuhan didalam hal informasi dan pelayanan.
\end{abstract}

Keywords: Pelayanan Publik, Cloud Computing, Pemodelan, Desa Pintar

\section{PENDAHULUAN}

Perkembangan teknologi semakin berkembang dengan sangat pesat, saat ini revolusi industri 4.0 menjadi konsep utama pemerintah didalam pengembangan keilmuan yang ada di indonesia. Semua kegiatan berbasiskan internet of things dan terintegrasi satu sama 
lainnya, revolusi industri 4.0 juga menuntut kita untuk mengembangkan berbagai bentuk pelayanan yang bisa dilakukan dimana saja kapanpun dan setiap saat. Mengikuti perkembangan revolusi industri 4.0 tersebut saat ini perangkat mobile menjadi media utama yang sangat mendukung untuk perkembangannya.

Pelayanan publik merupakan kebutuhan yang tidak bisa ditawar-tawar didalam peningkatan mutu pelayanan setiap saatnya, setiap instansi maupun organisasi yang memberikan pelayanan publik tentunya ingin memberikan pelayanan terbaik kepada setiap orang yang dilayaninya. Saat ini pelayanan publik yang ada di desa Beringin Taluk Kec. Kuantan Tengah Kab. Kuantan Singingi sudah dilakukan dengan sangat baik namun ada beberapa kendala didalam hal pelayanan publik tersebut seperti belum adanya tempat penyimpanan data yang aman sehingga data mudah hilang dan rusak. Belum adanya integrasi antara BUMDes yang ada didesa sehingga informasi-informasi tidak bisa ditinjau secara berkala. Belum adanya media informasi ataupun media aduan dan keluhan yang terintegrasi sehingga masyarakat perlu datang langsung kekantor desa untuk mencari informasi dan memberikan aduan, begitu juga dengan kebutuhan masyarakat didalam hal pengurusan surat menyurat dimana masyarakat sering kesulitan mendapat informasi persyaratan setiap surat yang dibutuhkan dan juga sering terjadinya kesalahan-kesalahan didalam pengetikan data masyarakat.

Berdasarkan masalah yang muncul diatas maka muncul sebuah gagasan dan ide untuk memodelkan sebuah pelayanan publik desa untuk menuju desa yang pintar dan terintegrasi didalam pelayanan publik yang berbasiskan cloud computing yang mengukuti perkembangan industri 4.0 sehingga memudahkan perangkat desa maupun masyarakat untuk saling berinteraksi dan berbagi informasi. Menghasilkan sebuah model aplikasi untuk pelayanan publik desa yang terintegrasi berbasis cloud computing, memudahkan peninjauan secara berkala oleh perangkat desa dan masyarakat dan langkah mencapai tujuan menjadi smart village mengikuti perkembangan revolusi industri 4.0.

\section{TINJAUAN PUSTAKA}

\subsection{Pemodelan}

Pemodelan secara umum, dimengerti sebagai proses merepresentasikan objek nyata atau realita sebagai seperangkat persamaan matematika, grafis ataupun bagan agar mudah dipahami oleh pihak yang berkepentingan. Lebih khusus lagi, istilah ini sering digunakan untuk proses menggambarkan konsep yang mewakili obyek-obyek dalam pengembangan sistem informasi. Pemodelan dalam pengembangan sistem informasi, berevolusi selaras perkembangan teknologi dan metodologi pengembangannya. Kesamaan pandang diperlukan dalam pemodelan, yang akhirnya menuntut adanya keseragaman atau standar. Teknologi obyek, membutuhkan pemodelan yang relevan, telah mendorong Jacobson dkk, menciptakan standar pemodelan untuk pengembangan sistem, dengan pendekatan obyek yang dikenal dengan UML (Unified Modeling Language). UML memiliki keuntungan yang menghasilkan representasi yang dapat diverifikasi melalui penalaran logis, pengujian, atau bahkan simulasi. Sebagai contoh, diagram proses bisnis dapat diuji dengan mental melewati kasus imajinasi, melalui pemikiran logis yang mungkin berbeda untuk melihat apakah itu merupakan upaya menghasilkan output yang diperlukan. Ada tiga jenis pemodelan, seperti yang digambarkan di bawah ini :

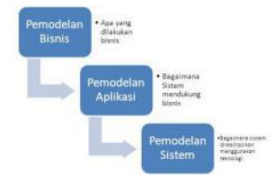

\section{Gambar 2.1 Jenis Pemodelan}


Hal : 87 - 95

\subsection{Unified Modeling Language (UML)}

Menurut Satzinger, Jackson, dan Burd (2011), "Unified Modeling Language (UML) is the standard set of model construct and notations defined by the Object Management Group (OMG), a standart organization for system development." Yang terjemahannya adalah Unified Modeling Language (UML) merupakan kumpulan model standar kontruksi dan notasi yang didefinisikan oleh Object Management Group (OMG), yang adalah sebuah organisasi standart untuk pengembangan sistem.

Menurut Shelly dan Rosenblatt (2012), "The Unified Modeling Language (UML) is a widely used method of visualizing and documenting software systems design.", yang terjemahannya adalah Unified Modeling Language (UML) adalah metode yang digunakan secara luas memvisualisasikan dan mendokumentasikan desain sistem perangkat lunak.

Berdasarkan pengertian diatas dapat disimpulkan bahwa Unified Modeling Language (UML) adalah metode yang diginkan untuk dapat memodelkan dan mengembangkan sistem sesuai dengan keinginan user yang dapat menghasilkan model atau desain sistem perangkat lunak.

\subsection{Konsep Pelayanan Publik}

Pelayanan pada dasarnya dapat didefinisikan sebagai aktivitas seseorang, sekelompok atau organisasi baik langsung maupun tidak langsung. Kamus Bahasa Indonesia (2007:646), pelayanan memiliki tiga makna, (1) perihal atau cara melayani, (2) usaha melayani kebutuhan orang lain dengan memperoleh imbalan (uang), (3) kemudahan yang diberikan sehubungan dengan jual beli barang atau jasa.

Sinambela dalam bukunya yang berjudul "Reformasi Pelayanan Publik" (2014:5) menyatakan bahwa: "Pelayanan adalah pemberian layanan (melayani) keperluan orang atau masyarakat yang mempunyai kepentingan pada organisasi itu sesuai dengan aturan pokok dan tata cara yang telah ditetapkan".

\subsection{Cloud Computing}

Pengertian Cloud Computing menurut Onno w Purbo (2011:6) mengemukakan bahwa cloud computing adalah sebuah model komputasi / computing, dimana sumber daya seperti processor / computing power, storage, network, dan software menjadi abstrak dan diberikan sebagai layann di jaringan / internet menggunakan pola akses remote. Model billing dari layanan ini umumnya mirip dengan modem layanan publik. Ketersediaan on-demand sesuai kebutuhkan, mudah untuk di kontrol, dinamik dan skalabilitas yang hampir tanpa limit adalah beberapa atribut penting dari cloud computing.

Menurut jurnal yang dipublikasikan IEEE, Internet Computing/Cloud Computing adalah suatu paradigma dimana informasi secara permanen tersimpan di server di internet dan tersimpan secara sementara di komputer pengguna (client) termasuk di dalamnya adalah desktop, komputer tablet, notebook, handheld, sensor-sensor, monitor dan lain-lain.

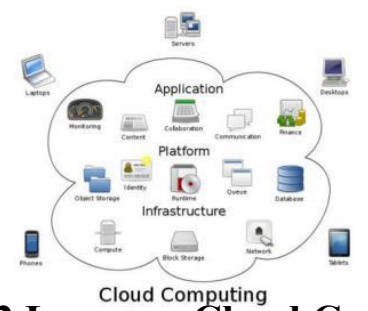

Gambar 2.2 Layanan Cloud Computing 
Hal : $87-95$

\section{METODE PENELITIAN}

Berdasarkan analisa-analisa yang di uraikan maka dapat di lihat tahapan penelitian ini pada gambar 3.1.

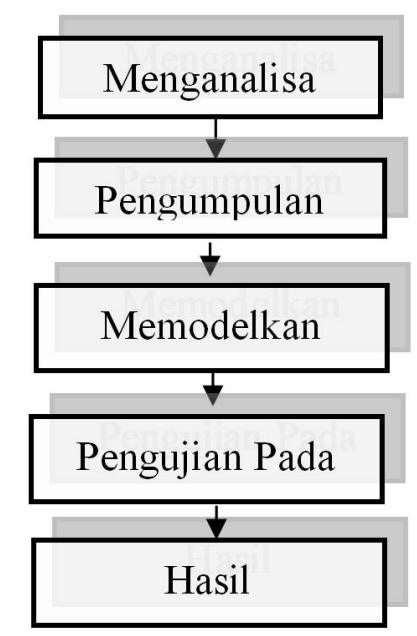

\section{Gambar 3.1 Prosedur Penelitian}

\subsection{Menganalisa Masalah}

Langkah menganalisa masalah adalah langkah untuk dapat memahami masalah yang telah ditentukan dalam ruang lingkup atau batasannya. Dengan menganalisa masalah yang ditentukan tersebut, maka masalah dapat dipahami dengan baik. Masalah yang timbul sekarang adalah bagaimana memodelkan aplikasi pelayanan publik desa dalam memcapai tujuan menjadi smart village.

\subsection{Pengumpulkan Data}

Dalam pengumpulan data dan informasi, pada tahap ini dilakukan untuk mengetahui mengenai sistem yang diteliti. Dari data dan informasi yang dikumpulan akan didapat data untuk pendukung penelitian. Metode yang digunakan penulis untuk pengumpulan data dengan berbagai metode sebagai berikut :

a. Observasi

Melakukan pengamatan langsung di tempat penelitian untuk mengetahui secara jelas dan terinci permasalahan yang ada. Pengamatan langsung dilalukan pada Desa Beringin Taluk.

b. Interview

Dilakukan untuk memperoleh informasi atau data yang dibutuhkan dengan cara melakukan wawancara langsung pada bagian yang terkait yaitu pada perangkat Desa tersebut.

c. Studi Literatur

Dalam metode ini informasi dikumpulkan dengan membaca jurnal dan buku - buku yang berhubungan dengan tesis untuk menunjang dalam melakukan analisa terhadap data dan informasi. Di antara buku yang berkaitan dengan pelayanan publik dan jurnal yang berkaitan dengan penelitian. 
Hal : 87 - 95

\section{HASIL DAN PEMBAHASAN}

\subsection{Use Case Model Diagram}

Use Case Diagram menggambarkan sekelompok use case dan actor yang disertai dengan hubungan diantaranya. Diagram ini menggambarkan fungsionalitas yang diharapkan dari aplikasi smart village yang dapat mengintegrasikan kegiatan BUMDes dan kegiatan Desa lainnya. Use case diagram menampilkan apa - apa saja yang bisa dilakukan oleh seorang aktor/pengguna didalam mengelola aplikasi.

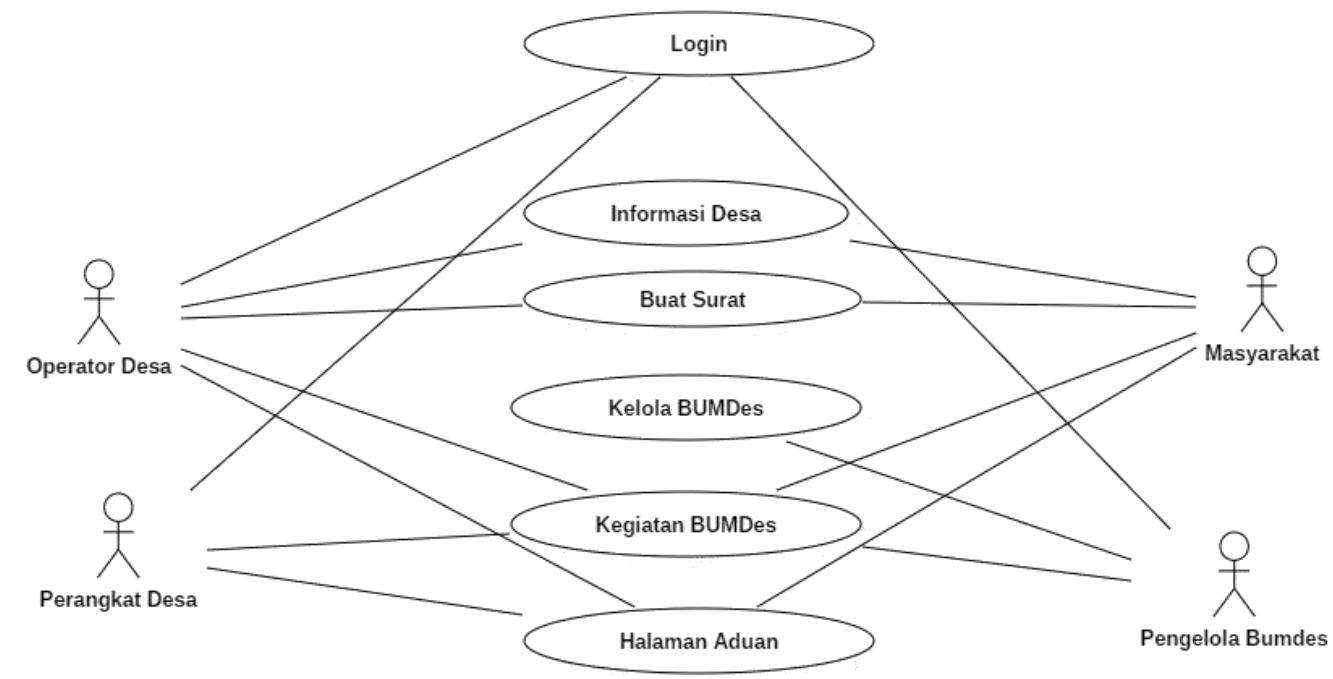

Gambar 4.1 Use Case Diagram

Dari use case diagram diatas dapat kita lihat bagaimana alur kerja yang dilakukan antara actor dan use case untuk lebih jelasnya berikut keterangan gambar diagram datas :

1. Use Case Login pada gambar diatas dapat diakses oleh 3 aktor yaitu Operator Desa, Perangkat Desa dan pengelola BUMDes.

2. Actor Operator desa untuk dapat mengelola case lainnya seperti informasi desa, case ini dikelola Operator Desa untuk mengupdate informasi dan pemberitahuan kepada Masyarakat. 3. Actor masyarakat dapat mengakses case Buat Surat yang digunakan Masyarakat untuk membuat surat-surat yang dibutuhkan, sehingga memudahkan masyarakat untuk mengurus surat karena masyarakat hanya tinggal mengambil hasil suratnya kekantor desa.

4. Pada case lainnya masyarakat juga dapat melihat informasi desa, melihat laporan kegiatan-kegiatan BUMDes, dan memberikan aduan kepada perangkat Desa.

5. Pada actor perangkat desa berperan untuk melihat aduan dari masyarakat dan laporan kegiatan BUMDes.

6. Actor pengelola BUMDes dapat megelola dan mengupload bukti dan laporan kegiatan BUMDes yang dilelola oleh masing-masing pengelola. Sehingga BUMDes menjadi terintegrasi terhadap semua pihak.

\subsection{Pemodelan Aplikasi}

Pemodelan aplikasi ini akan menampilkan model ataupun user interface dari aplikasi smart village berbasiskan cloud computing yang akan diimplementasikan kedalam bentuk sebuah aplikasi pada platform android dan pengelolaan datanya kedalam sebuah cloud computing yang terintegrasi. Adapun bentuk model dari aplikasi ini dapat dilihat pada gambar-gambar berikut : 


\section{Halaman Utama}

Halaman utama dari aplikasi ini digunakan oleh semua actor yang akan menggunakan aplikasi, dimana setiap actor bisa melihat Informasi Desa, Buat Surat, informasi kegiatan BUMDes dan Aduan. Seluruh data akan tersimpan secara cloud computing Halaman ini diutamakan untuk actor masyarakat. Untuk lebih jelasnya bisa dilihat pada gambar 4.1 dibawah ini :
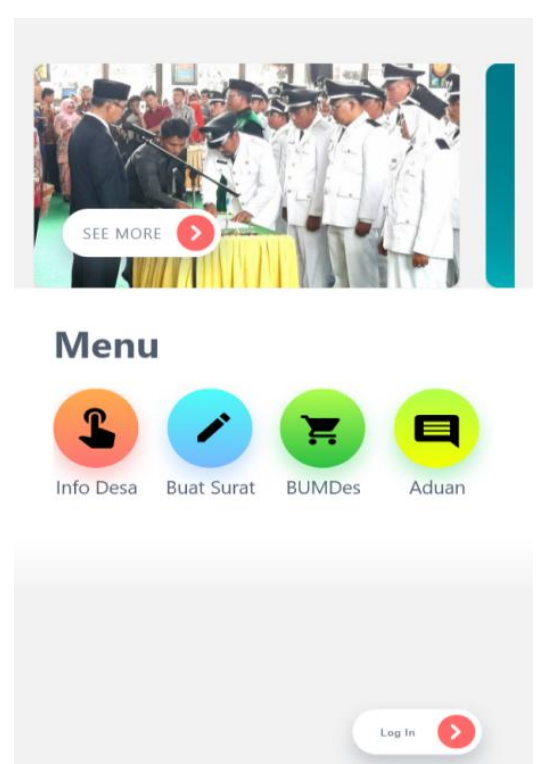

\section{Gambar 4.1 Halama Utama Smart Village}

\section{Halaman Login}

Halaman ini dapat diakses oleh 3 actor yaitu Operator Desa, Pengelola BUMDes dan Perangkat Desa. Halaman ini digunakan actor untuk masuk kedalam sistem pengelolaan masing-masing actor. Untuk lebih jelasnya bisa dilihat pada gambar 4.2 dibawah ini :

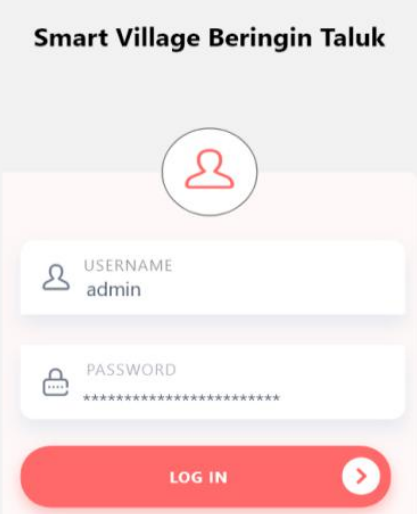

Gambar 4.2 Halaman Login Smart Village 
$\mathrm{Hal}: 87-95$

\section{Halaman Utama Operator Desa}

Pada halaman utama operator desa ini actor OP Desa dapat melakukan pengelolaan data seperti input informasi desa, melihat data pembuatan surat, melihat laporan kegiatan BUMDes dan melihat aduan yang masuk dari masyarakat. Untuk lebih jelasnya bisa dilihat pada gambar 4.3 dibawah ini :

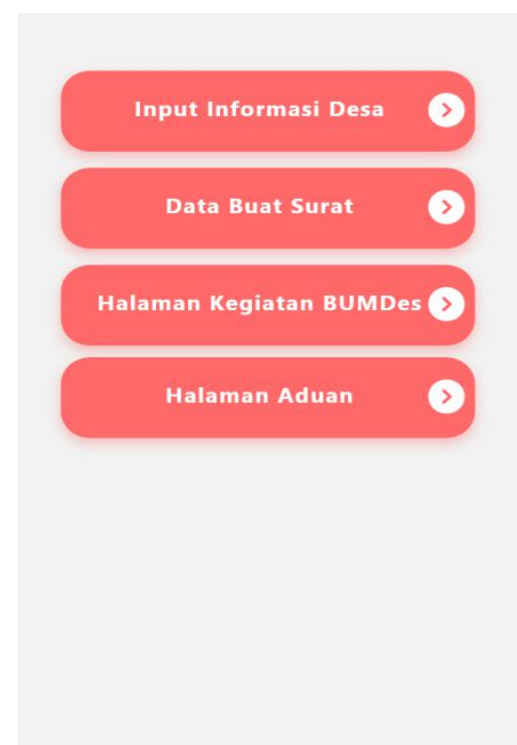

\section{Gambar 4.2 Halaman Login Smart Village}

\section{Halaman Informasi Desa}

Halaman ini digunakan untuk melihat informasi dan berita kegiatan Desa secara Up to Date, sehingga informasi seperti canang desa bisa tersampaikan kemasyarakat dengan cepat dan lebih akurat. Untuk lebih jelasnya bisa dilihat pada gambar 4.4 dibawah ini :

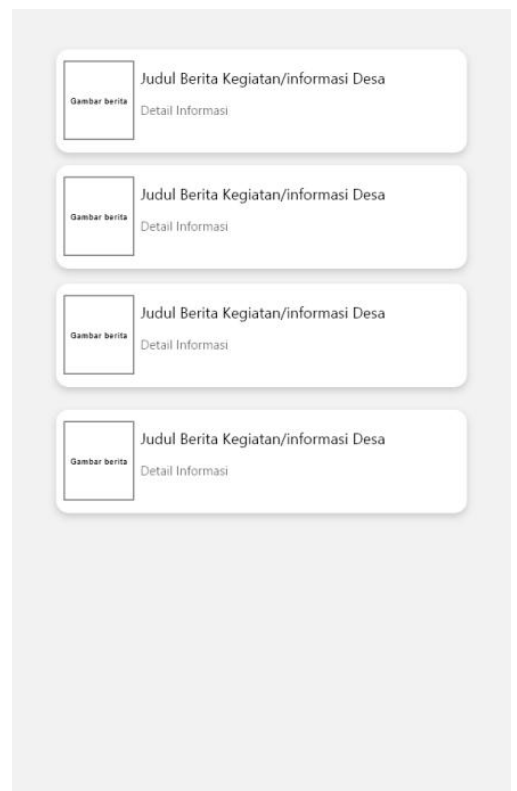

Gambar 4.4 Halaman Informasi Desa 
$\mathrm{Hal}: 87-95$

\section{Halaman Kegiatan BUMDes}

Halaman ini adalah halaman yang digunakan untuk menampilkan informasi keuangan pada BUMDes yang ditampikan secara transparan dan bisa dilihat oleh seluruh masyarakat desa. Proses pelaporan keuangannyapun menjadi lebih mudah. Untuk lebih jelasnya bisa dilihat pada gambar 4.5 dibawah ini :

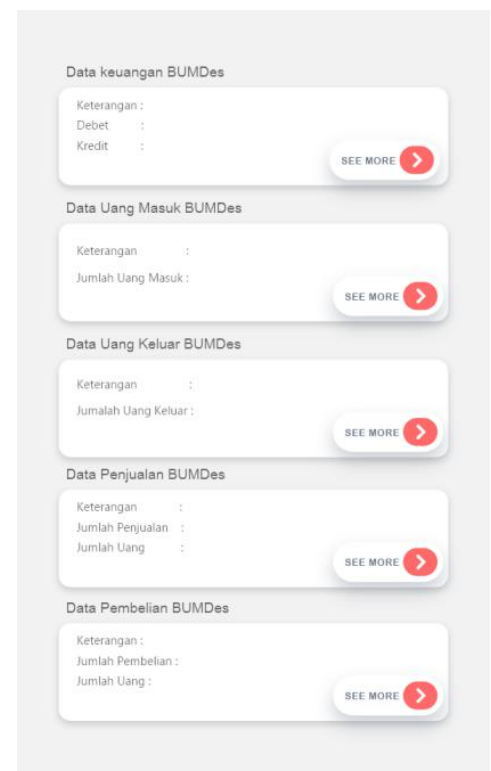

\section{Gambar 4.5 Halaman Kegiatan BUMDes}

\section{Halaman Aduan Masyarakat}

Halaman ini digunakan oleh masyarakat untuk menyampaikan aduan ataupun keluhan terhadap aparatur/pemerintahan desa sehingga semua aduan dapat diterima dan segera diproses oleh perangkat desa. Untuk lebih jelasnya bisa dilihat pada gambar 4.6 dibawah ini :

Tuliskan Aduan Anda

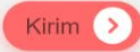

Gambar 4.6 Halaman Aduan Masyarakat 
Hal : 87 - 95

\section{SIMPULAN}

Berdasarkan penelitian yang telah dilakukan maka dapat disimpulkan hasil penelitian ini adalah :

1. Aplikasi smart village ini dapat membuat semua data kegiatan Desa menjadi saling terintegrasi karena tersimpan secara cloud computing.

2. Aplikasi ini dapat membantu masyarakat dalam pengurusan surat menyurat dadn terjadi keterbukaan publik antara masyarakat dan perangkat desa dalam pengelolaan BUMDes.

\section{UCAPAN TERIMAKASIH}

Alhamdulillah, puji syukur selalu peneliti hantarkan kepada Allah SWT yang telah menganugerahkan rahmat, taufik dan berkah-Nya sehingga peneliti dapat menyelesaikan dengan baik. Peneliti juga ingin menyampaikan ucapan terimakasih yang tak terhingga dan penghargaan setinggi-tingginya kepada Civitas Akademika Universitas Islam Kuantan Singingi.

\section{DAFTAR PUSTAKA}

Abdurohman, M. et al. (2012). "Perancangan Aturan Transformasi UML - Systemc dalam perancangan Embedded System”. Jurnal Ilmu Komputer dan Informasi. 3 (2): 17-23.

Ferro Bayu Saputro. et al. (2017) "Pengembangan Sistem Kuliah Online Universitas Diponegoro Untuk Antar Muka Mahasiswa Pada Perangka Bergerak Berbasis Android" Jurnal Transmisi 19 (1).

Helliyatul Matlubah. et al. (2016) “Aplikasi Mobile Learning Berbasis Smartphone Android Sebagai Sumber Belajar Mahasiswa Program Studi Pendidikan Ipa Universitas Wiraraja Sumenep"Jurnal Lentera Sains (Lensa) 6 (2): 85-98.

Nazli, R (2015) "Pemodelan Game Edukasi Matematika Untuk Meningkatkan Kualitas Berhitung Penjumlahan Angka Pada Anak Usia Dini” Saintikom Uniks 2 (1): 156-164.

Nazli, R (2018) "Pemodelan Aplikasi Mobile Modul Perkuliahan Berbasis Client Server" Jurnal Teknologi dan Open Source 1(1) 25-32.

Purbo, Onno W. 2011. One Day Future Networking. Yogyakarta: Synaptic UII

Sinambela, Lijan Poltak. 2008. Reformasi Pelayanan Publik Teori, Kebijakan, dan Implementasi. Jakarta : PT Bumi Aksara

J. W. Satzinger, R. B. Jackson and S. D. Burd, Systems Analysis and Design in a Changing World, Sixth ed., 2011.

Shelly, Gary B., and Harry J. Rosenblatt. (2012). Systems Analysis and Design Nineth Edition. United States of America: Course Technology. 